\title{
Prevalence Of Human Papillomavirus And Co- existent Sexually Transmitted Infections Among Female
}

Ilka Kassandra Pereira Belfort ( $\square$ ilkabelfort@gmail.com )

Universidade Federal do Maranhão https://orcid.org/0000-0002-0734-0353

Carla Figueredo Belfort Leite

Universidade Federal do Maranhao

Francisco Pedro Belfort

Universidade Federal do Maranhao

Renata Lemos Gaspar

Universidade Federal do Maranhao

Pablo Matos Monteiro

Universidade Federal do Maranhao

Lucas Henrique de Lima Costa

Universidade Federal do Maranhao

Ana Paula Almeida Cunha

Universidade Federal do Maranhao

Flávia Castello Branco Vidal

Universidade Federal do Maranhao

Allan Kardec Duailibe Barros

Universidade Federal do Maranhao

Sally Cristina Moutinho Monteiro

Universidade Federal do Maranhao

Research article

Keywords: Papillomaviridae, Street Drugs, Sexually Transmitted Diseases,health promotion

Posted Date: October 9th, 2019

DOI: https://doi.org/10.21203/rs.2.15771/v1

License: (1) (1) This work is licensed under a Creative Commons Attribution 4.0 International License.

Read Full License 


\section{Abstract}

Background: human papillomavirus is one of the most common sexually transmitted infections in the world, with a higher prevalence among young adults at the onset of sexual activity,

Methods: prospective cross-sectional study were performed among 162 women aged between 18 and 73 years. For the DNA/HPV isolation, samples were collected and placed in the HC2 DNA Collection buffer (QIAGEN, CA, USA), and frozen at $-20^{\circ} \mathrm{C}$ until processed. DNA/HPV extraction were performed by using QIAamp DNA Mini and Blood kit (QIAGEN, CA, USA) according to manufacturer instructions. Total DNA was isolated, eluted in $100 \mathrm{~mL} \mathrm{AE}$ buffer and stored at $80^{\circ} \mathrm{C}$. Extracted DNA was quantified using a NanoVue unit (GE Healthcare Life Sciences, Little Chalfont, UK). Statistical analysis was performed using IBM SPSS ${ }^{\circledR}$ software version 23. Data were initially subjected to descriptive analysis, plus mean and standard deviation.

Results: among the participants, $61.7 \%$ had DNA / HPV and $66.7 \%$ were users of illicit drugs and $59.3 \%$ were non-users, making them statistically significant. Among DNA/HPV positive users there was a higher proportion of sexually transmitted infections (STIs) $(27.9 \%)$ compared to non-users $(9.27 \%)(p>0.05)$.

Conclusion: the vulnerability of women to STIs and the high influence caused by the socioeconomic context in the course of these infections, the importance of public policies that establish appropriate strategies for their prevention, early diagnosis and treatment is emphasized, so that there is. The Research Ethics Committee of the University Hospital of the Federal University of Maranhão approved the project under the number CAAE 76328917.5.0000.5086, and informed consent was obtained from all subjects.

\section{Background}

Human papillomavirus (HPV) is one of the most common sexually transmitted infections (STIs) in the world, with a higher prevalence among young adults at the onset of sexual activity (WENDLAND et al., 2018a). Approximately 291 million sexually active women come into contact with the virus during their lifetime (WORLD HEALTH ORGANIZATION, 2013), but infection can be eliminated without developing clinical signs within 12 months (DUARTE et al., 2017; GRADÍSSIMO, BURK, 2017). In Brazil, according to the preliminary results of the Epidemiological Study on the National Prevalence of HPV Infection (POPBrazil), the estimated prevalence of HPV is $54.6 \%$, with a mean age of 20.6 years (BRASIL, 2017).

Currently more than 200 types of HPV have been identified and can be classified as low oncogenic risk when associated with the development of warts and benign lesions or high oncogenic risk when associated with the development of cancer. Persistent high-risk HPV infection, including types 16 and 18, are at increased risk of developing cervical intraepithelial lesions that may progress to cervical cancer (CAMARGO et al., 2018; GOODMAN, 2015). HPV has been reported as responsible for at least $99 \%$ of cervical cancers worldwide (SERRANO, et al., 2017, WHO, 2010), and is associated with the development 
of other types of cancer of the genital tract in men and women, such as penile cancer and anal cancer (VIARISIO, GISSMANN, TOMMASINO, 2017).

Cervical cancer is the third most frequent tumor in the female population and the fourth leading cause of cancer death in Brazil (INCA, 2018; IARC, 2012), accounting for 16,340 (7.9\%) new cases and 5,430 deaths per year, according to the National Cancer Institute (INCA, 2016). The high prevalence of HPV is associated with demographic, socioeconomic and sexual behavior (GOODMAN, 2015, WOLDAY et al., 2018). Among the demographic and socioeconomic factors, there are schooling and low income, as well as the difficulty in accessing health services; in relation to factors associated with sexual behavior, there are huge number of partners, the early onset of the sexual activity, multiparity and condom non-use. (GUIMARÃES et al., 2018; DEV et al., 2006).

Studies have reported that persistent HPV infection is facilitated by inflammatory processes caused by other sexually transmitted agents, such as Chlamydia trachomatis, Thichomonas vaginalis and Treponema pallidum (WOLDAY et al., 2018; LUGO, et al., 2018). In addition, coinfections elevate the risk of progression to malignancy probably due to increased impairment of the immune system (VRIEND et al., 2015). The vaginal microbiota influences the innate and adaptive responses of mucosal and cutaneous surfaces, differing according to the site of infection of the virus, favoring the elimination or persistence of HPV infection in the infected tissue (SCHIFFMANN et al., 2016).

Illicit drug users are exposed to additive and intoxicating effects of drugs, which alter judgment and inhibition, often causing impulsive and unsafe sexual behaviors such as multiple partners and unprotected sex (without condom use) (GUIMARÃES et al., 2018; WENDLAND et al., 2018a; PAQUETTE et al., 2017; DEV et al., 2006; PLITT, et al., 2007; RAWSON, et al., 2002), and in the present study. Although addiction affects sexual behavior in different ways, it can lead to the exchange of sex for drugs and / or money, innumerable anonymous partners, and a greater likelihood of relating to social networks with a high prevalence of STIs (WENDLAND et al., 2018a; PAQUETTE et al., 2017; PLITT, et al., 2007; SEMPLE, et al., 2005; RAWSON, et al., 2002).

Some studies report a higher prevalence of STls among young adults between the ages of 16 and 44 who are illicit drug users (PAQUETTE et al., 2017; DEGENHARDT; HALL, 2012). There are few published studies on STIs in the drug user population, as assessed in general household surveys. Thus, information on sexual and reproductive health behaviors are important for the development of effective preventive strategies against anogenital cancers in this population. The objective of this study was to determine the prevalence rates of HPV infection and coinfection by other STIs in women who use illicit drugs.

\section{Methods}

\section{Study Population}

This prospective cross-sectional study were performed among 162 women aged between 18 and 73 years, who have been patients at the public health units of gynecological care in São Luís - MA, Brazil 
from August 2017 to September 2018. Exclusion criteria included menstruation, hysterectomy, women who did not start sexual activity, pregnant or at less than 45 days postpartum.

Before the questionnaire administration, willing participants were given all the necessary information about the study, before they signed the informed consent form. A structured standardized questionnaire was administered to obtain detailed data on socio-demographic characteristics, and sexual, reproductive and gynecologic history. These data included age, literacy, marital status, ethnicity, age at first intercourse, parity, lifetime number of sexual partners, methods of contraception and history of IST infections.

We define drug users in this chapter as those who are addicted to the use of opiates (e.g., heroin), cocaine (e.g., freebase and crack), and methamphetamine (meth), and marijuana.

The Research Ethics Committee of the University Hospital of the Federal University of Maranhão approved the project under the number CAAE 76328917.5.0000.5086, and informed consent was obtained from all subjects. The free and informed consent form was obtained through signatures of the participants.

\section{Cervical cytology and sexually transmitted infection}

Conventional cytological smears were obtained with Ayres spatula (ectocervical sample) and endocervical brush (endocervical sample), extended in a glass slide, fixed with ethanol, and stained using the Pap technique. Cytological examinations of Pap smear were reported using the 2001 Bethesda Reporting System. Microbiological findings such as Candida sp., Trichomonas vaginalis, Gardnerella vaginalis, Lactobacillus $s p$, coccus andother bacilli were also identified through the cytological test.

The presence of virus da hepatite B - HBV (VIKIA HBsAg, bioMérieux Brasil), virus da hepatite C - HCV (Imuno- Rápido HCV da Wama Diagnóstica)), virus da imunodeficiência - HIV (HIV Tri Line, Bioclin, Brasil) and Syphilis (DPP® Rapid Test Syphilis Biomaguinhos) were determined by using rapid tests based on immunochromatographic method device or strip, according to the manufacturer's instruction.

\section{Specimen collection from DNA extraction}

For the DNA/HPV isolation, samples were collected and placed in the $\mathrm{HC}_{2}$ DNA Collection buffer (QIAGEN, CA, USA), and frozen at $-20^{\circ} \mathrm{C}$ until processed. DNA/HPV extraction were performed by using QIAamp DNA Mini and Blood kit (QIAGEN, CA, USA) according to manufacturer instructions. Total DNA was isolated, eluted in $100 \mathrm{~mL} A E$ buffer and stored at $-80^{\circ} \mathrm{C}$. Extracted DNA was quantified using a NanoVue unit (GE Healthcare Life Sciences, Little Chalfont, UK).

\section{Detection of HPV}


Presence from DNA/HPV was detected using nested polymerase chain reaction (PCR) with the primer sets PGMY09/11 (first round PCR) and GP+5/GP+6 (second round PCR); these primers amplify a segment of the L1 gene and evaluated by amplification of the human $\beta$-globin gene.

The first round of amplification was carried out in a $25 \mu \mathrm{L}$ reaction volume by using $5 \mu \mathrm{L}$ DNA, $8.7 \mu \mathrm{L}$ water, $2.5 \mu \mathrm{L}$ 10X PCR buffer (10 mM Tris-HCl, pH 8.5, $50 \mathrm{mM} \mathrm{KCl),} 1.5 \mathrm{mM} \mathrm{MgCl}$, $10 \mathrm{mM}$ each dNTP, 30 $\mu \mathrm{M}$ each primer (MY09 and MY11), and $0.5 \mu \mathrm{L}$ Platinum Taq DNA polymerase (Invitrogen). Amplification was performed according to the following protocol: 35 cycles at $94^{\circ} \mathrm{C}$ for 30 seconds, $51.5^{\circ} \mathrm{C}$ for 30 seconds, $72^{\circ} \mathrm{C}$ for 30 seconds, followed by a final step at $72^{\circ} \mathrm{C}$ for 7 minutes. The second amplification was also carried out in a $25 \mu \mathrm{L}$ reaction volume by using $5 \mu \mathrm{L}$ amplified DNA, 9.7 $\mu \mathrm{L}$ water, $2.5 \mu \mathrm{L} 10 \mathrm{X}$ PCR buffer, $1.5 \mathrm{mM} \mathrm{MgCl2,} 10 \mathrm{mM}$ of each dNTP, $30 \mu \mathrm{M}$ of each primer (GP5+ and GP6+), and $0.5 \mu \mathrm{L}$ Platinum Taq DNA polymerase. Amplification was performed as follows: $94^{\circ} \mathrm{C}$ for 5 minutes, followed by 45 cycles at $94^{\circ} \mathrm{C}$ for 45 seconds, $40^{\circ} \mathrm{C}$ for 60 seconds, and $72^{\circ} \mathrm{C}$ for 60 seconds, and a final step at $72^{\circ} \mathrm{C}$ for 10 minutes.

Amplification products were evaluated by electrophoresis on a $1.5 \%$ agarose gel in $1 \mathrm{X}$ TBE buffer for 30 minutes at $5 \mathrm{~V} / \mathrm{cm}$ in a horizontal unit (Life Technologies, Carlsbad, CA, USA). Bands were stained with $0.1 \%$ Gel Red (Invitrogen) and visualized using an ultraviolet transilluminator (BioRad Laboratories, Hercules, CA, USA).

\section{Data Analysis}

Statistical analysis was performed using IBM SPSS ${ }^{\circledR}$ software version 23. Data were initially subjected to descriptive analysis, plus mean and standard deviation. The Kolmogorov-Smirnov test was used to verify the normality of data. The Student t-test was used to evaluate associations between groups of the independent variables with normal distribution. The results were considered statistically significant when $p<0.05$.

\section{Results}

The study group consisted of 162 women, divided into two groups: users of illicit drugs and non-users of illicit drugs, with a mean age of 34.3 years, with illicit drug users in age group from 18 to 30 years (45\%).

With regard to sociodemographic data, it was verified that among the drug users $64.81 \%$ completed the average level; $61.10 \%$ were self-described with brown skin color and $57.40 \%$ were single. As far as sexual behavior is concerned, $70.37 \%$ of drug users are: first coitus between 15 and 19 years; 53.7\% had more than 7 sexual partners so far; $74.07 \%$ and $83.33 \%$ practice oral and anal sex, respectively. The study participants are predominantly non-smokers (68.51\% among users and $90 \%$ among non-users) and make steady use of alcoholic beverages, which exceeds the World Health Organization's recommendations (proportionally 2 doses per day or drink for 2 days). Regarding condom use, $75.92 \%$ of drug users say they do not use it while $62.03 \%$ of non-users use this barrier method in (Table 1 ). 
Table 1. Socio-demographic parameters of the study groups

\begin{tabular}{|c|c|c|c|}
\hline & $\begin{array}{l}\text { Drug Users } \\
\qquad N=54\end{array}$ & $\begin{array}{l}\text { Not Drug Users } \\
\qquad N=108\end{array}$ & $p$ \\
\hline $\begin{array}{l}\text { Age distribution } \\
18 \text { a } 30 \\
31 \text { a } 43 \\
44+\end{array}$ & $\begin{array}{l}13(24 \%) \\
27(50 \%) \\
14(25,92)\end{array}$ & $\begin{array}{l}26(45 \%) \\
64(33,33) \\
18(16,67)\end{array}$ & $\mathrm{p}<0.01$ \\
\hline $\begin{array}{l}\text { Education } \\
\text { Illiterate } \\
\text { Primary and Middle } \\
\text { High school } \\
\text { University }\end{array}$ & $\begin{array}{c}1(1,87 \%) \\
13(24,07 \%) \\
35(64,81 \%) \\
5(9,25 \%) \\
\end{array}$ & $\begin{array}{c}5(4,62 \%) \\
50(46,29 \%) \\
28(25,92 \%) \\
25(23,14 \%)\end{array}$ & $\mathrm{p}<0.01$ \\
\hline $\begin{array}{l}\text { Race/ethnicity } \\
\text { Preta } \\
\text { Branca } \\
\text { Parda }\end{array}$ & $\begin{array}{c}21(38,88 \%) \\
02(3,70 \%) \\
31(57,40 \%)\end{array}$ & $\begin{array}{l}43(39,81 \%) \\
65(60,19 \%)\end{array}$ & $\mathrm{p}<0.01$ \\
\hline $\begin{array}{l}\text { Married status } \\
\text { Single } \\
\text { Married/living together }\end{array}$ & $\begin{array}{l}30(55,55 \%) \\
24(44,44 \%)\end{array}$ & $\begin{array}{l}40(37,03 \%) \\
68(62,97 \%)\end{array}$ & $\mathrm{p}<0.01$ \\
\hline $\begin{array}{l}\text { Age at first intercourse } \\
11 \text { a } 14 \\
15 \text { a } 19 \\
20 \text { a } 24\end{array}$ & $\begin{array}{c}7(1,85 \%) \\
40(27,78 \%) \\
7(1,85 \%)\end{array}$ & $\begin{array}{l}13,(19,5 \%) \\
25,(46,30 \%) \\
41,(12,04 \%)\end{array}$ & $\mathrm{p}<0.01$ \\
\hline $\begin{array}{l}\text { Number sexual partners } \\
1 \text { a } 2 \\
3 \text { a } 6 \\
7+\end{array}$ & $\begin{array}{c}5(9,27 \%) \\
20(37,03 \%) \\
29(53,7 \%) \\
\end{array}$ & $\begin{array}{c}60(55,55 \%) \\
38(35,18 \%) \\
10(9,27 \%) \\
\end{array}$ & $\mathrm{p}<0.01$ \\
\hline $\begin{array}{l}\text { Practice of anal sex } \\
\text { Yes } \\
\text { No }\end{array}$ & $\begin{array}{l}40(74,07 \%) \\
14(25,93 \%)\end{array}$ & $\begin{array}{l}60(55,55 \%) \\
48(44,45 \%)\end{array}$ & $\mathrm{p}<0.01$ \\
\hline $\begin{array}{l}\text { Practice of oral sex } \\
\text { Yes } \\
\text { No }\end{array}$ & $\begin{array}{c}45(83,33 \%) \\
9(16,67 \%)\end{array}$ & $\begin{array}{l}63(58,33 \%) \\
45(41,67 \%)\end{array}$ & $\mathrm{p}<0.01$ \\
\hline $\begin{array}{l}\text { Smoking } \\
\text { Yes } \\
\text { No }\end{array}$ & $\begin{array}{l}17(31,49 \%) \\
37(68,51 \%) \\
\end{array}$ & $\begin{array}{c}10(9,26 \%) \\
98(90,74 \%)\end{array}$ & $\mathrm{p}<0.01$ \\
\hline $\begin{array}{l}\text { Alcohol } \\
\text { Yes } \\
\text { No }\end{array}$ & $\begin{array}{l}36(66,66 \%) \\
18(33,34 \%)\end{array}$ & $\begin{array}{l}70(64,81 \%) \\
38(35,19 \%)\end{array}$ & $\mathrm{p}<0.01$ \\
\hline $\begin{array}{l}\text { Anticoncepcional Oral } \\
\text { Yes } \\
\text { No }\end{array}$ & $\begin{array}{c}3(5,56 \%) \\
51(94,44 \%)\end{array}$ & $\begin{array}{l}14(12,97 \%) \\
94(87,03 \%)\end{array}$ & $\mathrm{p}<0.01$ \\
\hline $\begin{array}{l}\text { Condom use } \\
\text { Yes } \\
\text { No }\end{array}$ & $\begin{array}{c}23(42,6 \%) \\
41(75,92 \%)\end{array}$ & $\begin{array}{l}67(62,03 \%) \\
31(57,4 \%)\end{array}$ & $\mathrm{p}<0.01$ \\
\hline
\end{tabular}


The results of the preventive tests (Table 2) showed that $88.88 \%$ of drug users and $92.59 \%$ of non-users presented cytological data with no malignancy / alterations. However, illicit drug users have a higher percentage of cytologic changes (low grade SIL + high grade SIL - 11.1\%) than nonusers (7.4\%), which are statistically significant.

Table 2. Cytology Diagnosis in the Study Groups

\section{Drug Users Not Drug Users $\quad P^{*}$}

$$
\mathbf{N}=\mathbf{5 4} \quad \mathbf{N}=\mathbf{1 0 8}
$$

\begin{tabular}{l|l|l|l}
\hline Normal & $48(88,88 \%)$ & $100(92,59 \%)$ & $p<0.01$ \\
\hline Low grade SIL & $3(5,55 \%)$ & $4(3,7 \%)$ & $p<0.03$ \\
\hline High grade SIL & $3(5,55 \%)$ & $4(3,7 \%)$ & $p<0.03$ \\
\hline
\end{tabular}

*T - Student e Qui-Quadrado

Among the participants, $61.7 \%$ had DNA / HPV and $66.7 \%$ were users of illicit drugs and $59.3 \%$ were nonusers, making them statistically significant. Among DNA/HPV positive users there was a higher proportion of sexually transmitted infections (STIs) $(27.9 \%)$ compared to non-users $(9.27 \%)(p>0.05)$ (Table 3).

Table 3. Prevalence of HPV and STIs by Genital HPV Infection Status in the Study Groups

\begin{tabular}{l|c|c|c|c|c|c}
\multicolumn{4}{c}{} & \multicolumn{4}{c}{ Drug Users } & \multicolumn{4}{c}{ Not Drug Users } \\
N=54 & HPV+ & HPV- & & HPV+ & HPV- & \\
\hline & HPV+ & & \multicolumn{1}{c}{$\mathbf{N}=108$} & \\
\hline HPV & $36(66,7 \%)$ & $18(33,33 \%)$ & $>0,05$ & $64(59,3 \%)$ & $44(40,74 \%)$ & $>0,05$ \\
\hline Candida & $5(9,3 \%)$ & $4(7,4 \%)$ & $>0,05$ & $7(6,5 \%)$ & $12(11,11 \%)$ & $>0,05$ \\
\hline Trichomonas & $5(9,3 \%)$ & $1(1,85 \%)$ & $>0,05$ & $1(0,92 \%)$ & $0(0 \%)$ & $>0,05$ \\
\hline Syphilis & $5(9,3 \%)$ & $0(0 \%)$ & $>0,05$ & $2(1,85 \%)$ & $2(1,85 \%)$ & $>0,05$ \\
\hline
\end{tabular}

*Não foram encontradas participantes com teste reativo para HCV (hepatite C), HBsAg (hepatite B) e HIV (vírus da imunodeficiência humana).

Table 4 shows the co-infections in women with DNA / HPV positive, where HPV is frequently associated with another infectious agent in both groups. In both users and non-users, the percentage of co-infections is similar $(61.1 \%$ and $58.33 \%$, respectively $-p<0.05)$. This data configures that both groups are exposed to more than one type of IST in their relationship environments.

Table 4. Prevalence of co-infection in women with HPV+ in the Study Groups 


\begin{tabular}{|c|c|c|c|}
\hline & $\begin{array}{c}\text { Drug Users } \\
\mathbf{N}=54\end{array}$ & $\begin{array}{c}\text { Not Drug Users } \\
\mathbf{N}=108\end{array}$ & $p$ \\
\hline HPV & $1(1,85 \%)$ & $3(2,77 \%)$ & $<0.02$ \\
\hline HP & 16 & 35( & $<0.02$ \\
\hline HPV - & 16( & $22(20,37 \%)$ & $<0.02$ \\
\hline HPV + 3 IST & $6(5,55 \%)$ & $1(1,85 \%)$ & $<0.02$ \\
\hline
\end{tabular}

*T - Student e Qui-Quadrado

\section{Discussion}

As predicted by Goodman (2015) and Wolday (2018), the high prevalence of HPV is related to socioeconomic, demographic, and sexual behavior. According to Dev et al., (2006) and Guimaraes (2018), demographic and socioeconomic factors are related to: low level of schooling, low income and sexual behavior, which includes high number of partners, early sexual activity, lack of condom use and multiparity.

Thus, the results of this research are in agreement with the authors, since it was found that the participants in our research do not have much study because, among the participants of the group of illicit drug users, the majority $(64,81 \%)$ only have secondary education and those of the non-users group, the majority (46.29\%) only have elementary education. In Machado's (2017) research, it corroborates with our data that high school is preponderant in the results of the researched ones confirming the importance of the level of schooling in the prevention of diseases, especially the transmissible ones.

Miranda et al. (2013), referring to the level of education, clarifies that the higher the educational level, the greater the concern about the danger of contracting STIs, as well as the interest and understanding of the content about prevention presented to them. Therefore, the low educational level of the women interviewed in our study may justify the $61.7 \%$ rate of DNA/HPV.

As a significant difference among users of illicit drugs, it was found that $70.37 \%$ had the first coitus between 15 and 19 years; $53.7 \%$ had more than 7 sexual partners so far; $74.07 \%$ practice oral sex and $83.33 \%$ anal sex.

Regarding age, Queiroz, Cano and Zaia (2007) report that HPV infection has a higher incidence among women in the age group between 20 and 40 years, since in this age group, sexual practice is more frequent. They also emphasize that it is in this age group that the disease presents its most latent form, and that because of this, its identification becomes more difficult, a fact that facilitates the transmission.

Sharing the same thinking, Sellors et al. (2003) states that HPV infection is 3 to 4 times more prevalent in young adult women than in women aged 35-55 years. (SELLORS et al., 2003 apud NAKAGAWA, SCHIRMER, BARBIERI, 2010).

Corroborating with our findings, Fedrizzi (2011) argues that sexual behavior, such as large numbers of partners and early initiation of sexual activity, are factors that relate to HPV virus contamination and also 
to other types of STDs. Epidemiological studies on infection $(3,4)$ have documented a substantial preponderance in which, early age of sexual debut and low adherence to condom use constitute risk factors for both infection and reinfection by HPV.

Among the participants in the positive DNA/HPV study, there was a higher proportion of sexually transmitted infections (STIs) among illicit drug users (27.9\%) when compared to non-users $(9.27 \%)$ ( $p>$ $0,05)$.

According to the National Cancer Institute (INCA), it is proven that $50 \%$ to $80 \%$ of women with active sex life will have some type of infection caused by one or more types of HPV at some point. It reports that most of these infections will be transient, due to the immune system fighting them, especially among younger ones. However, it emphasizes that although the immune system develops antibodies, they will not always be sufficient to fight and eliminate viruses (INCA, 2019).

In the words of Simões and Zanusso Júnior $(2019,104)$ it is had that:

[...] Human Papilloma Virus (HPV) infection is the main risk factor for cervical cancer. Other factors have been identified as at risk, such as socioeconomic and environmental and lifestyle, which include early onset of sexual activity, plurality of sexual partners, smoking, inadequate hygiene habits and prolonged use of oral contraceptives. In the early stages cervical cancer is asymptomatic, and the discovery of the disease is done through the result of cytopathological examination (Papanicolaou) that should be done regularly.

However, for Rosa et al (2009), only the presence of HPV does not constitute sufficient reason for the presence of malignancy, since only a small percentage is that it evolves into cancer and when there is the presence of high oncogenic risk and pre-malignant lesions that persist for decades.

Among the different types of viruses classified as high-risk, Campisi (2009) and Scudellari (2013), report that the highest risk for causing infections are HPV-16 and HPV-18, when compared to the other types, once that these are associated to the DNA of the host, being associated in a world-wide level, to the cases of cancer. The authors also say that the vaccine becomes a preventive option, but it only acts as a preventive way, in people who had access to it before they started sexual life.

When associated with HPV + and other STIs in drug users we had syphilis as the main related infection $(9.3 \%)$. Compared to data from the Epidemiological Bulletin of Syphilis we had a lower but worrying percentage, since studies indicate the return of this epidemic in Brazil (BRASIL, 2018). In a study by Lopes et al. (1997) in a Brazilian penitentiary reported that the prevalence of active syphilis in the studied population was (5.7\%) which they are numbers that draw near to those found in our study. In view of the above, we see the need for strengthening in the incentive and dissemination in the realization of rapid tests offered in basic health units.

The results of the preventive tests showed that $88.88 \%$ of drug users and $92.59 \%$ of non-users presented cytological data with no malignancy / alterations. However, illicit drug users have a higher percentage of 
cytologic changes (low grade SIL + high grade SIL - 11.1\%) than nonusers $(7.4 \%)$, which are statistically significant.

Among the users of illicit drugs, the risk of STI contamination becomes much greater, due to sexual behaviors being mostly impulsive and insecure, with unprotected sex and with multiple partners (GUIMARÃES et al., 2018; WENDLAND et al., 2018a).

It was evidenced in the research that among users of illicit drugs, $74.07 \%$ and $83.33 \%$ practice anal and oral sex respectively; $94.44 \%$ do not take contraceptives. However, we did not identify relation between contraceptive and higher risk for infection (ENTIAUSPE, et al, 2014).

In fact, drug users are a population with a high index of vulnerability to HIV infection, both due to the proper forms of drug use with needle sharing and other materials in the non-parenteral use, as well as through the practice of non-insurance, which often reverts to one of the ways they can get the drugs they use (ROSS, WILLIAMS, 2001).

According to Caiaffa et al. (2006), in the late 1980s and mid-1990s injecting drug users (IDUs) were most responsible for the country's HIV epidemic.

In this way, it is perceived that drug users constitute a population that must be constantly vigilant, since the contagion of the various STIs occurs, in the great majority, among those who live a disorderly life and without great concern for hygiene and health. In addition, the transmission of HPV occurs in various ways, either by contact between the sex organs, in anal intercourse that can lead to viral infections and neoplasias, and even through oral sex (ROSA et al., 2009).

The prevention of the virus is based mainly on the adoption of condoms during sexual intercourse by both women and men, and preventive exams such as the pap smear that detects in early time existent neoplasias (CIRINO; ICHIATA: BORGES, 2010).

It should be emphasized that the National Cancer Institute (INCA, 2019) states that persistent infection, caused by HPV, plays a major role in the development of cervical cancer, since studies show that the virus is present in more of $90 \%$ of confirmed cases of cervical cancer.

\section{Conclusion}

In this study, we identified a higher probability of positive HPV associated with other STIs for the following women: single, brown, middle school, alcohol-consuming, and multiple partners.

In this context and in view of the vulnerability of women to STIs and the high influence caused by the socioeconomic context in the course of these infections, the importance of public policies that establish appropriate actions / strategies for their prevention, early diagnosis and treatment is emphasized, so that there is promotion in the quality of life of this population. 


\section{Declarations}

\section{AUTHORS' CONTRIBUTION}

All the authors contributed to the project construction, evaluation, data collection and article validation.

\section{FUNDING}

The HPV Study infrastructure is supported by the Maranhão Tumor and DNA Bank (BTMA - UFMA). Similarly, FAPEMA provided financial support for data analysis.

\section{ACKNOWLEDGEMENT}

This research was supported in part by research funding from the Maranhão Scientific and Technological Research and Development Foundation (FAPEMA). The opinions expressed in this article are those of the authors.

We thank the Family Health Strategy teams, the women surveyed, the HPV Research Group and the participating Health Units.

\section{References}

[1]WENDLAND, E. M. et al. Sexual behavior across the transition to adulthood and sexually transmitted infections. Medicine, v. 97, n. 33, p. e11758, 2018a.

[2]WORLD HEALTH ORGANIZATION (WHO). Sexually Transmitted Infections (STIs). [s.l: s.n.].

[3]DUARTE, D. V et al. Prevalence of Human Papillomavirus Infection and Cervical Cancer Screening among Riverside Women of the Brazilian Amazon. Revista Brasileira de Ginecologia e Obstetricia, v. 39, n. 7, p. 350-357, 2017.

[4]GRADÍSSIMO, A.; BURK, R. D. Molecular tests potentially improving HPV screening and genotyping for cervical cancer prevention. Expert Review of Molecular Diagnostics, v. 17, n. 4, p. 379-391, 2017.

[5]BRASIL. Dados do Boletim Epidemiológico de Síflis-2018. Disponivel em: http://www.aids.gov.br/ptbr/pub/2018/boletim-epidemiologico-de-sifilis-2018. Acesso em 16 de meio de 2019.

[6]LOPES, F. et al. Prevalência de HIV, papilomavírus humano e sífilis na Penitenciária Feminina da Capital, São Paulo, 1997-1998. Cad. Saúde Pública, Rio de Janeiro, 17(6):1473-1480, nov-dez, 2001.

[7]GOODMAN, A. HPV testing as a screen for cervical cancer. BMJ, v. 350, p. 1-11, 2015. 
[8]SERRANO, B.; BROTONS, M.; BOSCH, F. X.; BRUNI, L. Epidemiology and burden of HPV-related disease. Best Pract. Res Clin Obstet Gynaecol. 2017 Sep 2. pii: S1521-6934(17) 30124-4.

[9]WORLD HEALTH ORGANIZATION (WHO). Immunization, Vaccines and Biologicals. Última atualização: setembro de 2010. Disponível em: www. who.int/immunization/topics/hpv/en/. Acesso em novembro 2017.

[10]VIARISIO, D.; GISSMANN, L.; TOMMASINO, M. Human papillomaviruses and carcinogenesis: wellestablished and novel models. Current Opinion in Virology, v. 26, p. 56-62, 2017.

[11]INSTITUTO NACIONAL DO CÂNCER (INCA). Detecção Precoce. 2001. Disponível em: http://www2.inca.gov.br/wps/wcm/connect/acoes_programas/site/home/nobrasil/prog rama_nacional_controle_cancer_colo_utero/deteccao_precoce. Acesso em: 02 maio de 2019.

[12]IARC. Globocan 2012: Estimated cancer incidence, mortality and prevalence worldwide in 2012. Data sources and methods. Disponível em: http://globocan.iarc.fr/Pages/DataSource_and_ methods.aspx. Acesso em outubro de 2017.

[13]WOLDAY, D. et al. HPV genotype distribution among women with normal and abnormal cervical cytology presenting in a tertiary gynecology referral Clinic in Ethiopia. Infectious Agents and Cancer, v. 13, n. 1, p. 28, 2018.

[14]GUIMARÃES, R. A. et al. Risk behaviors for sexually transmitted infections in noninjecting drug users: A cross-sectional study. International Journal of STD \& AIDS, p. 095646241775033, 2018.

[15] DEV, D. et al. Incidence of and risk factors for genital human papillomavirus infection in women drug users. Journal of Acquired Immune Deficiency Syndrome, v. 41, n. 4, p. 527-529, 2006

[16]VRIEND, H. J. et al. Incidence and persistence of carcinogenic genital human papillomavirus infections in young women with or without Chlamydia trachomatis co-infection. Cancer Medicine, v. 4, n. 10, p. 1589-1598, 2015.

[17]SCHIFFMAN, M. et al. Carcinogenic human papillomavirus infection. Nature Reviews Disease Primers, v. 2, 2016.

[18]PAQUETTE, R. et al. Illicit drug use and its association with key sexual risk behaviours and outcomes: Findings from Britain's third National Survey of Sexual Attitudes and Lifestyles (Natsal-3). PLoS One, v. 12, n. 5, p. 1-17, 2017.

[19]PLITT, S. S.; SHERMAN, S. G.; VISCIDI, R. P.; STRATHDEE, S. A.; FULLER, C. M., [20]RAWSON, R. A.; WASHTON, A.; DOMIER, C. P.; RIEBER, C. Drugs and sexual effects: Role ofdrug type and gender. Journal of Susbtance Abuse Treatment. v. 22;103-108. 2002. 
[21]SEMPLE, S. J.; ZIANS. J.; GRANT, I.; PATTERSON, T,L. Impulsivity and methamphetamine use. Journal of Substance Abuse Treatment. v. 29; 2005;85-93.

[22]DEGENHARDT, L.; HALL, W. Extent of illicit drug use and dependence, and their contribution to the global burden of disease. The Lancet, v. 379, n. 9810, p. 55-70, 2012.

[23]MIRANDA, A.E; RIBEIRO, D.; REZENDE, E. F.; et al. Associação de conhecimento sobre DST e grau de escolaridade entre conscritos em alistamento ao Exército Brasileiro. Brasil, 2007. Cien Saude Colet. v. 18; n. 2 ; 2013. P. $489-497$.

[24]Machado LS, Pires MC. Perfil epidemiológico de mulheres com papilomavírus humano que utilizam o serviço público de saúde. Rev baiana enferm., v. 3, n. 4:e22135. 2017;

[25]QUEIROZ, A.M. A.; CANO, M. A. T.; ZAIA, J. E. O papiloma vírus humano (HPV) em mulheres atendidas pelo SUS, na cidade de Patos de Minas-MG. Revista Brasileira Análise Clínica, Rio de Janeiro, v. 39, n. 2; p. 151-157. 2007.

[26]NAKAGAWA,J; TAMANI, T; S.; J; BARIERI, M. Vírus HPV e câncer de colo de útero.Rev Brasileira de Enfermagem. [en línea], 63, abr.2010.

[27]FEDRIZZI, E. N. Epidemiologia da infecção genital pelo HPV. Rev Bras Pat Trato Gen Inf. v. 1; n.1; 2011.

[28]CAMPISI, G.; GIOVANNELLI, L. Controversies surrounding human papiloma vírus infection, head and neck vs oral câncer, implications for prophylaxis and treatment. Head Neck Oncol. v.30;n.1; 2009.

[29]SIMÕES, LUDMILA PINI; ZANUSSO JUNIOR, GERSON. Vírus HPV e o desenvolvimento de câncer de colo de útero: uma revisão bibliográfica.Rev. UNINGÁ, Maringá, v. 56, n. 1, p. 98-107, jan./mar. 2019 [30]WENDLAND, E. M. et al. POP-Brazil study protocol: A nationwide cross-sectional evaluation of the prevalence and genotype distribution of human papillomavirus (HPV) in Brazil. BMJ Open, v. 8, n. 6, p. 1$6,2018 b$.

[31]ROSS, M.; WILLIAMS, M. L. Sexual behavior and illicit drug use. Annu Rev Sex Res. v. 12; n.1; 2001:290-310.

[32]ENTIAUSPE LG, et al. High incidence of oncogenic HPV genotypes found in women from Southern Brazil. Braz J Microbiol; v. 45, n. 2, p. 689-94. 2014.

[33]CAIAFFA, W. T.; BASTOS, F.; FREITAS, L. L. The contribution of two Brazilian multi-center studies to the assessment of HIV and HCV infection and prevention strategies among injecting drug users: the AjUDEBrasil I and II Projects. Cad. Saúde Pública,v.22 n.4; 2006: 771-782. 
[34]CIRINO, F. M. B.; NICHIATA, L. Y. I.; BORGES, A. L. V. Conhecimento, atitude e práticas na prevenção do câncer de colo uterino e HPV em adolescentes. Esc Anna Nery. Rev Enferm. v.14; n. 1; 126-34. 2010. 